\title{
A Methodological Approach to Assess the Potential of Non-Recycled Waste for Refuse Derived Fuels Material
}

\author{
Moh Nurhadi ${ }^{*}$ and Eddy Prianto ${ }^{2}$ \\ ${ }^{1}$ Energy Master Program, Postgraduate School of Diponegoro University, Semarang, Indonesia \\ ${ }^{2}$ Architechture Master Program, Faculty of Engineering, Diponegoro University, Semarang, Indonesia
}

\begin{abstract}
Modernization of waste processing through Waste-to-Energy has been a new trend to solve waste management and energy scarcity. This model however it may raise a conflict with recycling activities. This article establishes a methodological approach to assess Non-Recycled Waste for Refuse Derived Fuels materials. The approach is simulated by using calorific value of waste from Semarang Landfill which has calorific value 5,500 to $6,070 \mathrm{kcal} / \mathrm{kg}$ and waste composition of Banjarmasin Landfill which has been classified according to recycling perspective. The simulation shows that a low recycling rate (25\% plastic and paper taken for recycling) will produce $3,882 \mathrm{kcal} / \mathrm{Kg}$ while a high recycling rate $(50 \%)$ will produce 3,793 $\mathrm{kcal} / \mathrm{Kg}$. This simulation successfully calculates that non-recycled waste materials are still potential for RDFs materials.
\end{abstract}

\section{Introduction}

Waste-to-Energy (WtE) technology has been a new trend in modernizing waste processing because it can solve waste and energy scarcity problems [1]. WtE is an energy recovery process of waste through direct thermal conversion (incineration, pyrolysis, and gasification), or through fuel production in the form of methane, hydrogen, and other synthetic fuels [2]. The potential of $\mathrm{WtE}$ application is relied on local, regional, and national driving forces [3]. Energy from waste as renewable energy can substitute the use of and the stock of fossil energy that has been depleting. Moreover, global demand toward renewable energy is expected to increase six to seven times in the next decade [4].

Refuse Derived Fuels (RDF) is a solid fuels product of WtE that can be used based on the type of application for substituting or complementing fuels in several industrial sectors [5]. The use of RDF in cement industry due to its scale, can reduce fossil fuels consumption and greenhouse gases (GHG) emissions. The advantage of RDF is its low-cost production and high calorific value [6]. The energy content is extracted from plastic, paper, textile, wood, and other organic matters $[7,8]$. RDF production, however, raise a conflict with recycling activity because of material recycling and energy recovery trade-off. In fact, waste recycling

* Corresponding author: mohnurhadi@students.undip.ac.id 
materials give income and livelihood opportunities to recycling actors especially waste pickers [9].

Previous research in Indonesia and Asian countries show that municipal waste is potential for RDF production. In Semarang landfill, municipal waste has calorific value between 5,500 to $6,070 \mathrm{kcal} / \mathrm{kg}$ without recycling $[10,11,12,13,14]$. No research has been conducted in Indonesia to see energy potential while the municipal waste has been taken for recycling. While several research in Europe and Canada indicate that residue of recycling activities still has potential to be processed as RDF feeding $[15,16,17]$. Prioritization of material than energy recovery is recommended for waste management by several policies and other research $[18,19]$. Both clusters of research create a gap about the potential of non-recycled waste in Indonesia for RDF production? To fill the gap, this article proposes a methodological approach to assess the potential of non-recycled municipal waste using low and high recycling scenario.

\section{Theoretical Basis for Material \& Energy Recovery}

Although waste is generally considered as non-valuable materials, some types of waste still have economic value for recycling process [20]. Therefore the utilization and efficiency of resource use through waste minimization, long-term value retention, reduction of primary resources, and closed loop of products, product parts, and materials within the boundaries of environmental protection and socio-economic benefits called circular economics, are being promoted in international and national policy levels [21,22]. A circular economy has the potential to lead to sustainable development, while separating economic growth from the negative consequences will have resource depletion and environmental degradation effects [23].

The transition to a circular economy requires systemic change by minimizing waste and slowing down and closing the material and energy cycle. This transition promotes the reduction, reuse, recycling, and recovery of materials at different levels, aiming to achieve sustainable development [24].

\subsection{Material Recovery for Recycling}

In developing countries where resources and infrastructure for waste collection, transportation and disposal are very limited [25], much waste is not handled properly [26]. This untreated waste becomes a public good which is a source of livelihood and income generation for the poor [27]. Millions of people in India, Congo, Cameroon, and Nicaragua, and Mexico who because of poverty take valuable municipal waste to earn income and livelihoods [9,26,28,29].

Waste scavenging provides opportunities for individuals and households to participate in the formal economy by collecting valuable rubbish and selling it to suppliers or the recycling industry [20]. Scavenging plays an important role not only to fulfil the economic needs but also to create jobs and help environmental sustainability [28]. This waste collection and selling business to the recycling industry is a tangible form of the circular economy in waste management. Sorting and collecting recycled materials can reduce waste significantly. In India, scavenger activities can reduce $70 \%$ of plastic waste and turn it into a new resource [26]. In Indonesia, sorting and collecting recycled materials through a waste bank in Semarang can reduce the volume of plastic $17 \%$, paper 35\%, glass $20 \%$ and metal $66 \%$ [30]. Because of this role, several countries have considered to integrate waste scavenging activities into part of the formal economy, including Indonesia [31]. 
The significant role of waste scavenging can change with the modernization of waste management system. The use of modern technology, especially $\mathrm{WtE}$, requires high-heat waste such as plastic, paper and wood [32] while plastic and paper have high economic value for scavengers $[26,29]$. This conflict of interest eliminates scavenger control over valuable waste, thereby potentially eliminating scavenger livelihoods $[9,33]$. This process can occur in the RDF plant operations where high-calorific waste becomes a contested material.

\subsection{Energy Recovery through RDF Production}

Municipal waste is potential source for alternative energy. Several research show processing municipal waste could generate significant sustainable energy, reduce GHG emission as well as process waste properly $[2,10,11,16,17,18,32]$. Application of WtE in NSW Australia can generate $4,165 \mathrm{GWh} /$ year or equivalent to $5,9 \%$ of the installed electricity generation capacity [32]. The use of old waste in Semarang landfill is projected to produce 4.04 $\mathrm{GWh} /$ year [2]. High organic fraction and moisture municipal waste is still potential for RDF production in Banda Aceh, Indonesia [10], economically still feasible as indicated in Lampang Thailand [11]. Moreover, the utilization of RDF to substitute coal could give advantages for environment, financial saving and GHG emissions reduction as has been applied in Turkey [15], Canada [16], and Portugal [18].

$\mathrm{RDF}$ is defined as waste that is used wholly or partially for the purpose of energy generation that meets the quality criteria according to the regulation. The regulation measures quality based on the calorific value, size, and content of heavy metals so it requires some processing. RDF production requires certain calorie content which comes from various types of waste with high calorie content [34]. As fuels, RDF needs to comply to some criteria on calorific content, low chlorine, controlled composition, size, density, and certain quantity stock. Its specification will determine RDF utilization [17,34].

RDF specification in Indonesia has been suggested by the Ministry of Environment and Forestry guideline as shown in Table 1. A multi-stages sorting processes is needed to reduce incombustible waste fraction such as metal, gravel, ceramic, and glass, as well as to fulfil other criteria. However, it could not reduce the quantity of supply. These two considerations can be counterproductive where the tighter the quality, the smaller the quantities [34].

Table 1. Specification of RDF di Indonesia.

\begin{tabular}{|c|c|}
\hline Parameter & Value \\
\hline Calorific Value & $\geq 3000 \mathrm{kcal} / \mathrm{kg}$ (net) \\
\hline Moisture & $<20 \%$ \\
\hline Chlorine & $\leq 50 \mathrm{~mm}$ \\
\hline Size & $<1 \%$ \\
\hline Sulphur & Fluff \\
\hline Product Form & Not hazardous waste \\
\hline Others & \\
\hline
\end{tabular}

Source: KLHK [35]

\section{Research Methodology Design}


The research design is a series of logic that connects the required data with conclusions drawn from research questions [36]. The research question is what is the potential of non-recycled municipal waste in Semarang City as RDF raw material? To assess this potential, a literature review will be carried out on the recycled and non-recyclable waste, the combustible and incombustible municipal waste. This methodology sets up a basic waste classification to allow waste composition to be analysed in the perspective of material and energy recoveries.



Fig. 1. Research Flow Diagram

The study establishes recycling scenario that is intended to reduce uncertainty in variation of waste recycling. With scenario, type and level of recycling can be determined to allow analysis of potential energy from the remaining non-recycled waste. Waste composition data for each scenario is used to calculate the potential heat value of waste. The results of the calorific calculation of each scenario is compared with the minimum standard of RDF calorie to assess its potential as a raw material. 


\subsection{Waste Classification}

Classification of waste has differences and similarities from the perspective of material and energy recovery. Recycling often take out plastic including PET bottles and plastic bags; paper including cardboard and other paper; metal and glass [37]. For the purposes of recycling, plastic waste is broken down into PET, HDPE, LDPE, PP, PS, and PE, although different terms are used in the market. In addition to homogeneous plastic waste, there is heterogeneous plastic waste; combinations of two or more items known as multilayer plastic. This heterogeneous plastic waste has a low economic value. Paper waste is also divided in more detail classification because of the different selling prices. Similar classification is happened to metals and glasses [30]. For energy recovery purpose, waste is classified into incombustible waste including metal, asphalt, brick, soil, and glass; food waste, and combustible waste including plastic, paper, timber, and garden waste. Because of its heating value, plastics are further classified PET, HDPE, PVC, LDPE, PP, PS, PE. In paper waste, the type and heat value are not specified [32].

When material and energy recovery are compared, there are at least four classes of waste. First, waste is needed for energy recovery but is not intended for recycling. In this category are food waste, timber, garden waste, PVC, and multilayer plastic. Secondly the waste needed for recycling but not intended for energy recovery. Various types of metals and glass are included in this group. Third, waste needs for both material and energy recovery, resulting a conflict of utilization. In this category there are paper and plastic waste, especially PET, HDPE, rubber, and tires, as well as LDPE, PP, PS, and PE which are grouped into other plastics. The last category is waste that is unintended for both material and energy recovery, namely inert (soil, sand, gravel, and brick).

The four categories above are suggested to classified into 16 type of waste namely food waste, garden debris, timber, other organic waste, other plastic waste, leather and textile, iron/steel, aluminium, other metals, glass, paper, PET, HDPE, tyre and rubber, PVC dan inert.

\subsection{Development of Recycling Scenario}

Scenarios are an alternative picture of the future of an issue that become a focus of discussion, to provide a coherent framework for evaluation and comparison. The scenario approach has been widely used for sustainability issues since the mid-20th century until now including in energy, climate change and transportation sectors [38]. The scenario approach can be used to analyse how driving factors influence outcomes and assess uncertainty [39]. To determine the effect of recycling on the potential use of non-recycled waste as RDF raw material, the scenario approach is used to determine the level of recycling.

Conflict of utilization between material and energy recovery occurs in waste category 3 where plastic especially and paper waste are contested. To avoid uncertainty, the simulation uses three scenarios, energy recovery without recycling. All the waste transported to landfill is converted to RDF. The second scenario (low recycling) assumes that $25 \%$ of recycle materials in municipal waste is taken out for recycling. The residue (non-recycled waste) is recovered into RDF product. Scenario 3 (high recycling) assumes $50 \%$ of recycled materials are recovered and the residue is converted into RDF. Recycled fraction is only the municipal waste in category 3 , as described in previous section.

\subsection{Calculation of Calorific Value}

Calorific value of scenario 1 has been identified by previous research $[12,13,14]$ which is $5,500-6,070 \mathrm{Kcal} / \mathrm{Kg}$ of waste. Calorific value of scenario 2 and 3 will be calculated through conversion of calorie content in each type of waste. Total potential calorific content in the 
overall waste is a sum of calorific content in each waste type [32]. It can be written mathematically through the below equation:

$$
E h=\sum_{i=1}^{n} \text { LHVi.mfi.q }
$$

Where Eh is heat energy potential from all type of waste, LHVi (Low Heating Value) is calorific value of waste type $\mathrm{i}(\mathrm{kcal} / \mathrm{kg}$ ) while $m f i$ is fraction of waste type $\mathrm{i}$ (without unit). The value $q$ indicates total weight of waste.

The material recovery of plastic and paper according to scenario 2 and 3 will reduce the heat energy potential $(E h)$. The amount of calorie deduction is equal to the fraction of recycling. The heat energy of recycled fraction could be calculated using equation (2):

$$
\text { Ehr }=\sum_{i=1}^{n} \text { LHVi.mfi.rr.q }
$$

Where $E h r$ is heat energy from recycle waste taken while $r r$ is ratio of recycling. Value of $r r$ for scenario two is 0.25 (25\%) while scenario 3 is 0.5 (50\%) for PET, HDPE, LDPE, PP, PS, $\mathrm{PE}$, and paper. $L H V i$ is heat energy from a wet waste that influenced by its moisture. $L H V$ could be determined from $H H V$ (High Heat Value) with the following equation:

$$
L H V=H H V \cdot(1-w)-584,85 w
$$

Where $H H V$ is heat energy of a dry waste in $\mathrm{kcal} / \mathrm{kg}$, while w is water content and 584,85 is a heat constant in vaporizing water at temperature of $25^{\circ} \mathrm{C}$ [40].

Heat energy of non-recycled waste $(E h n)$ is accounted by deducting overall heat energy of waste $(E h)$ by heat energy of recycling waste $(E h r)$ through the equation below:

$$
E h n=E h-E h r
$$

\subsection{Determine the Potential for RDF Raw Material}

To assess the potential of non-recycled waste for RDF material, the average of calorific value of non-recycled waste $(E h n)$ in scenario 2 and 3 (in $\mathrm{kcal} / \mathrm{Kg}$ ) is compared to minimum standard of RDF. Minimum calorific value of waste for energy according to several literature and guideline is between $2,000-3,000 \mathrm{kcal} / \mathrm{kg}[35,41]$. When the calorific value of more than the minimum standard, it is potential for RDF materials and vice versa. Due to variation of minimum RDF calorific value requirement, the simulation will refer to the guideline for RDF production from municipal waste issued by the Ministry of Environment and Forestry the Republic of Indonesia which is $3,000 \mathrm{kcal} / \mathrm{Kg}$.

\section{Result and Discussion}

\subsection{Waste Classification}

To test the design research methodology, a new waste classification that consider material and energy recovery is needed. A detail waste classification has been applied by Mahyudin, Hadi and Purwanto [42] to assess recycled material collection in Basirih Landfill in Banjarmasin, South Kalimantan. The waste composition was originally been classified into 23 waste types. Considering calorific value of each waste type, the classification is simplified into 14 waste types through merging similar waste with the same calorific value. Various 
type of paper waste is merged into one category as paper while brick, concrete, inert and other waste is classified as inert. Various of metals have been merged as metals and low economic value of plastic which normally unpicked is classified as other plastic except PVC. PVC is classified differently because of its hazardous chlorine content while heated during thermal process [5].

Basirih Landfill receives 142.167 ton of municipal waste annually [42].

Table 2. Waste Weight and Composition according to the Proposed Category.

\begin{tabular}{|c|c|c|}
\hline Waste Type & $\%$ & $\begin{array}{c}\text { Weight } \\
\text { (Ton/year) }\end{array}$ \\
\hline Food Waste & 3.01 & 4,279 \\
\hline Garden Debris & 0.86 & 1,223 \\
\hline Timber & 3.01 & 4,279 \\
\hline Other Organic Waste & 55.78 & 79,301 \\
\hline Other Plastic Waste & 9.05 & 12,866 \\
\hline Leather and Textile & 0.1 & 142 \\
\hline Metals & 3.36 & 4,777 \\
\hline Glass & 2.18 & 3,099 \\
\hline Paper & 5.5 & 7,819 \\
\hline PET & 0.66 & 938 \\
\hline HDPE & 0.47 & 668 \\
\hline Tyre and Rubber & 7.2 & 10,236 \\
\hline PVC & - & - \\
\hline Inert & 8.82 & 12,539 \\
\hline
\end{tabular}

Source: reclassified from Mahyudin, Hadi, and Purwanto [42]

\subsection{Amount and Calorific Value of Waste}

In general, not all municipal waste could be processed into RDF. Incombustible waste must be taken out because it will reduce heat. The valuable incombustible materials such as metals and glasses could be collected for recycling while many types of inert is dumped in the landfill. Scenario 1 processes all types of combustible waste into RDF without recycling efforts. Based on this scenario, the waste processed into RDF includes all types of waste except metals, PVC, and inert. Amount of waste processed into RDF is 121,752 tons per year (85.64\%). Unprocessed waste of 20,415 tons per year is either taken for recycling or discharged during the RDF production.

Scenario 2 process all of combustible with $25 \%$ reduction of recyclable materials. Waste to be taken is paper, PET, HDPE and tyre and rubber. Amount of collected recyclable 


\section{ICENIS 2020}

materials is 4,915 ton per year while waste to be processed as RDF is 116.836 ton per annum $(82,18 \%)$.

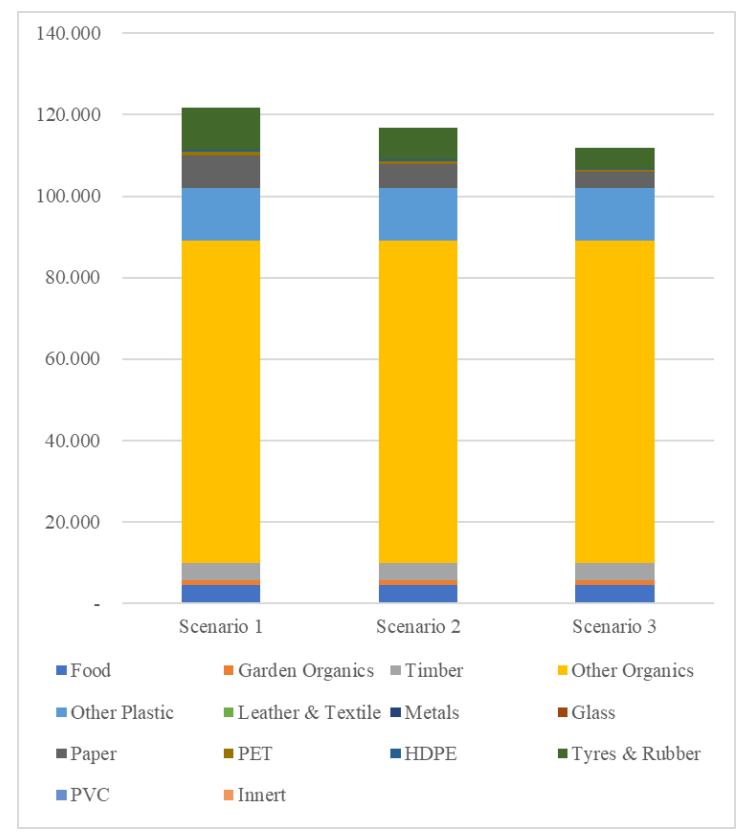

Fig. 2. Weight of waste for each scenario in ton

Scenario 3 takes $50 \%$ of paper, PET, HDPE, and tyre and rubber prior to process combustible waste into RDF. Amount of municipal waste to process as RDF is 111,921 ton per annum (78,73\%). Total material recovered for recycling is 9,831 ton per annum.

Heat energy calculation shows that scenario 1 produces the highest amount of heat energy 482,577.56 Gcal/year, scenario 2 produces 453,555.68 Gkal/year and scenario 3 results $424,533.81 \mathrm{Gkal} / \mathrm{year}$. The average of calorific value of scenario 1 is only $3.964 \mathrm{kcal} / \mathrm{Kg}$ while the actual calorific value of Semarang waste is $5,500-6,070 \mathrm{kkal} / \mathrm{Kg}$ [12]. This difference is likely due to different waste compositions between waste Jatibarang and Basirih Landfill. Jatibarang landfill has more amount of waste with high calorific value than Basilirih Landfill. Heat energy average in scenario 2 decreases to $3,882 \mathrm{kcal} / \mathrm{Kg}$ and scenario 3 is only $3,793 \mathrm{kcal} / \mathrm{Kg}$. However, all scenario produces heat energy more than the minimum requirement of RDF calorific value.

Table 3. Low Heat Value $(L H V)$ and amount of heat energy from non-recycled waste $(E h n)$

\begin{tabular}{|c|c|c|c|c|}
\hline Waste Type & $\begin{array}{c}\text { Low Heat } \\
\text { Value } \\
\text { (kcal/Kg) }\end{array}$ & Scenario 1 & Scenario 2 & Scenario 3 \\
\hline Food Waste & 456,30 & $1.952,61$ & $1.952,61$ & $1.952,61$ \\
\hline Garden Debris & $2.819,02$ & $3.446,64$ & $3.446,64$ & $3.446,64$ \\
\hline Timber & $3.542,89$ & $15.160,82$ & $15.160,82$ & $15.160,82$ \\
\hline Other Organic Waste & $2.768,85$ & $219.571,97$ & $219.571,97$ & $219.571,97$ \\
\hline
\end{tabular}




\begin{tabular}{|c|c|c|c|c|}
\hline Other Plastic Waste & $9.778,18$ & $125.807,14$ & $125.807,14$ & $125.807,14$ \\
\hline Leather and Textile & $3.874,96$ & 550,89 & 550,89 & 550,89 \\
\hline Metals & $-35,12$ & - & - & - \\
\hline Glass & $-174,40$ & - & - & - \\
\hline Paper & $3.521,39$ & $27.534,37$ & $20.650,78$ & $13.767,18$ \\
\hline PET & $5.219,97$ & $4.897,90$ & $3.673,43$ & $2.448,95$ \\
\hline HDPE & $9.732,79$ & $6.503,30$ & $4.877,48$ & $3.251,65$ \\
\hline Tyre and Rubber & $7.537,30$ & $77.151,93$ & $57.863,95$ & $38.575,97$ \\
\hline PVC & $4.536,71$ & - & - & - \\
\hline Inert & $-58,05$ & - & - & - \\
\hline Total & & $\mathbf{4 8 2 . 5 7 7 , 5 6}$ & $\mathbf{4 5 3 . 5 5 5 , 6 8}$ & $\mathbf{4 2 4 . 5 3 3 , 8 1}$ \\
\hline
\end{tabular}

In term of RDF quality (calorific value), material recovery in scenario 2 only reduce average of heat energy $2.06 \%$ while scenario 3 reduce heat energy for $4.30 \%$. average heat energy reduces insignificant because many high calorific value wastes remain available as RDF materials. It is mainly contributed by other plastic waste category which has LHV $9.778,18 \mathrm{kcal} / \mathrm{Kg}$ which is higher than any types of recycled waste. The amount of recycle materials taken both in scenario 2 and 3 in fact are less than the amount of other plastic waste. In term of quantity, however, the decrease of total heat energy of RDF is more significant. Total heat energy production in scenario 2 is only $453,555.68 \mathrm{Gcal} /$ annum or $6.01 \%$ less than scenario 1 . Total heat energy production is even lower with $12.03 \%$ less than scenario 1 . It indicates that even though material recovery does not imply significantly to average calorific value, but it can significantly reduce the quantity of RDF.

\section{Conclusion}

The results of energy content calculation in scenario 2 produces $3,882 \mathrm{kcal} / \mathrm{Kg}$ of waste while scenario 3 produces $3,793 \mathrm{kcal} / \mathrm{Kg}$ of waste. Both results indicate that municipal waste that has been taken its recycled material is still potential for RDF production. However total heat energy reduction is more significant than the average of calorific value. The designed research methodology is successful to estimate average and total heat energy production. It also successfully assesses the influence of material recovery in heat energy production. This simulation, however, produces a bias between actual calorific values as measured by Hutabarat et al. [12] and calorific value of the calculation using waste composition from Mahyudin, Hadi and Purwanto's research [42]. It is caused by the different composition of the waste. Therefore, it is necessary to assess potential of non-recycled waste for RDF production with the weight and composition of waste from the Jatibarang landfill itself. 


\section{References}

1. Byun, Y.; Cho, M.; Chung, J.; Namkung, W.; Lee, H.; Jang, S.; Hwang, S. Hazard Matter J. 190 (2011)

2. Lokahita, B.; Huboyo, H.; Samudro, G.; Aziz, M.; Takahashi, F. Jurnal Teknik Mesin (2018)

3. Lino, F.; Ismail, K. Resource Conservation \& Recycle 81 (2013)

4. Dudley, B. British Petroleum (2019)

5. Lorber, K.E; , Sarc, R. Waste to energy by preparation of quality controlled solid recovered fuels (SRF) in Proceedings of 4th ICET Conference (2013)

6. Hilber, T.; Maier, J.; Scheffknecht, G.; Agraniotis, M.; Grammelis, P.; Kakaras, E.; Torri, L. Journal of the Air \& Waste Management Association 57 (2007)

7. Pohl, M.; Gebauer, K.; Beckmann, M. Characterisation of Refuse Derived Fuels in view of the Fuel Technical Properties in 8th European Conference On Industrial Furnaces And Boilers (2008)

8. Garg, A.; Smith, R.; Hill, D.; Simms, N.; Pollard, S. Environmental Sciente \& technology, Vol. 41 (2007)

9. Hartmann, C. Waste Management 71 (2018)

10. Dianda, P., Mahidin, \& Munawar, E. Material Science and Engineering 334 (2017)

11. Srisaenga, N., Tippayawong, N., \& Tippayawong, K. Energetic and economic feasibility of RDF to energy plant for a local Thai municipality in proceeding $1 \mathrm{st}$ International Conference on Energy and Power, ICEP2016 (2017).

12. Hutabarat, I., Priyambada, I., Samudro, G., Lokahita, B., Syafrudin, Wardhana, I., \& Hadiwidodo, M. Jurnal Teknik Mesin (JTM): Vol. 07, No. 1 (2018).

13. Sembiring, L., Priyambada, I., Samudro, G., Lokahita, B., Wardhana, I., Hadiwidodo, M., \& Syafrudin. Jurnal Teknik Mesin (JTM): Vol. 07, No. 1 (2018).

14. Andrianingsih, R., Samudro, G., Budihardjo, M., Lokahita, B., Syafrudin, H. M., \& Wardhana, I. Jurnal Teknik Mesin (JTM): Vol. 07, No. 1 (2018).

15. Kara, M. Resource, Conservation and Recycling 68 (2012)

16. Reza, B., Soltani, A., Ruparathna, A., Sadiq, R., \& Hewage, K. Resources, Conservation and Recycling 81 (2013).

17. Bras, I., Silva, M., Lobo, G., Cordeiro, A., Fario, M., \& Lemos, L. Refuse Derived Fuel from Municipal Solid Waste rejected fractions- a Case Study in the Proceeding of the 11th European Conference on Industrial Furnaces and Boilers (2017)

18. Malinauskaite, J., Jouhara, H., Czajczyriska, D., Stanchev, P., Katsou, E., Rostkowski, P., Spencer, N. Energy 141 (2017).

19. RI. Undang-Undang Pengelolaan Sampah. (2008).

20. Oteng-Abbabio, M.; Arguello, JEM.; Gabbay, O. Habitat International 39. (2013)

21. Commission, E. COM/2015/0614. (2015).

22. SITRA. The Finnish Innovation Fund. Leading the Cycle - Finnish Road Map to a Circular Economy 2016-2025. (2016)

23. Babbitt, C., Gaustad, G., Fisher, A., Chen, W., \& Liu, G. Resour. Conserv. Recycl. 135. (2018)

24. Kirchherr, J., Reike, D., \& Hekkert, M. Resour. Conserv. Recycl. 127. (2017)

25. Guererro, LA; Maas, G.; Hogland, W. Waste Management 33 (1). (2013) 
26. Fiksel, J.; Lal, R. Environmental Development 26. (2018)

27. Zapata, P.; Campos, MJ. Habitat International 46 (2015)

28. Simatele, D; Etambakonga, CL. Habitat International 49. (2015)

29. Parrot, L.; Sotamenou, J; dan Dia, BK. Waste Management 29 (2009)

30. BINTARI. Improving Business Strategy Toward a Sustainable Waste Bank. (2020).

31. Scheinberg, A. Simpson, MH.; and Gupt, Y. "Economic Impacts of the Informal Sector in Solid Waste". Final revised report of the GTZ/CWG study of the same name.www.giz.de (2010)

32. Dastjerdi, B., Strezov, V., Kumar, R., \& Behnia, M. Renewable and Sustainable Energy Reviews 115. (2019).

33. Samson, M. Environment and Planning 33 (5). (2015)

34. Sarc, R.; Lorber, KE.; Pomberger, R.; Rogetzer, M.; Sipple, EM. Waste Management \& Research Vol. 37 (2019)

35. LHK. Pedoman Umum Pemanfaatan Sampah Rumah Tangga dan Sampah Sejenis Sampah Rumah Tangga Sebagai Bahan Bakar Alternatif Refuse Derived Fuel (RDF). (2015).

36. Rowley, J. Management Research News 25 (1) (2002).

37. Asim, M., Batool, S., \& Chaudry, M. Resources, Conservation and Recycling (2012).

38. Magnusson, T., Anderberg, S., Dahlgren, S., \& Svensson, N. Transportation Research Interdisciplinary Perspectives 5. (2020).

39. IPCC. Special Report on Emissions Scenario (2000).

40. Sokhansanj, S. The Effect of Moisture on Heating Values. Biomass Energy Data Book. (2011).

41. Damanhuri, E., \& Padmi, T. Pengelolaan sampah. Diktat Program Studi Teknik Lingkungan Institut Teknologi Bandung, 30 (2010).

42. Mahyudin, R., Hadi, S., \& Purwanto. Appl. Environ. Biol. Sci. (2015 ). 